\title{
The Effect of Think-Pair-Share Learning with Contextual Approach on Junior High School Students' Mathematics Problem Solving Ability
}

\author{
Choirul Abidin, Siti Maghfirotun Amin and Raden Sulaiman \\ Universitas Negeri Surabaya, Surabaya, 60231, Indonesia \\ choirulabidin16070785042@mhs.unesa.ac.id, sitiamin@unesa.ac.id
}

\begin{abstract}
The aim of this research was to find out the effect of Think-Pair-Share learning with contextual approach on students' mathematics problem solving ability. The static group comparison design was used as the research design. This research used test method with the research instrument of problem solving ability. The subject of the research was junior high school students, consisted of two groups, namely experimental group and control group. The experimental group was the class which was given treatment of Think-Pair-Share learning with contextual approach, while the control group was the class which was not given any treatment. The result of the research indicated that the students' problem-solving ability in the experimental group was better than the control group. This shows that ThinkPair-Share learning with contextual approach has an effect on students' problem solving ability. Therefore, Think-Pair-Share learning with contextual approach can be used as a reference to conduct learning in mathematics class as well as to train students' problem-solving ability. Further research that need to be conducted is to explore the increase of students' problemsolving ability on the different academic level.
\end{abstract}

Keywords- Effect, Think-Pair-Share, Contextual Approach, Problem Solving.

\section{INTRODUCTION}

Problem solving ability is required by students in various level of education because it is a competence that students must achieve in learning, especially mathematics learning. Students' mathematics problem solving ability cannot be separated from the learning process itself. Students are required to actively participate in the learning so that they can develop their ability in understanding material. [1]. In conducting the learning activity, teacher should also be able to motivate the students so that they are encouraged to do the learning activity enthusiastically. Besides, teacher also needs to relate the teaching material to the real life. One of them is using Think-Pair-Share learning with contextual approach.

Think-Pair-Share is one of cooperative learnings [19]. The Think-Pair-Share is a learning that provide an opprtunity for students to explore the ability of cooperation with other people, both their deskmates or classmates, expressing opinion or responding other students' opinion. Think-Pair-Share is an activity that prompts students to reflect on an issue or problem and then to share that thinking with others. Students are encouraged to justify their stance using clear examples and clarity of thought and expression [2]. There are three steps in Think-Pair-Share. They are 'think' (the first step), 'pair' (the second step) and 'share' (the third step) [3]. 'Think' step is a step of opportunity for students to think to solve problem individually. In 'pair' step, students discuss with their friends in pairs. There is exchange of information, experience and etc in this step. On the next step, 'share', students share infromation to the larger area such as other pairs or to the classroom. Generally the steps in this learning are: firstly teacher poses a question or problem for students to be found the solution and to be solved, then gives time for students to solve the problem with their own ideas and ways, after that the students discuss their thought result in pairs and teacher asks them to share the discussion result to their classmates. ThinkPair-Share learning model offers a learning process to a more challenging activity, which is started by involving students to think about a problem given by a teacher [4]. The following are the steps of Think-Pair-Share learning according to Nyunt and Tint [2]. Think - Individually: Each student thinks about the task given by teacher. They are given time to write their own ideas or response before discussing it with their partners. Pair - With partner: Students are asked to sit with their partner. Each student pair discusses their ideas about the task and their previous ideas. By discussing, each pair will result an answer they agree on. Share - To all learners: Students are asked to share the discussion result in front of the classroom. At this step, there will be a large discussion. Teacher will facilitate the discussion so that the students can think, ask or respond.

Think-Pair-Share is a learning model developed by combining independent learning and group learning. According to Lie [7], Think-Pair-Share is a learning model which can encourage students to work individually or in group. The characteristics of Think-Pair-Share is that there are thinking (think), pairing (pair) and presenting the discussin result/ sharing ideas (share) [3]. On the think stage, students think to solve problem individually. In this stage, teacher gives a problem or poses a question and ask the students to think to solve the problem individually. On the pair stage, students are given an opportunity to discuss the problem given by teacher in pairs. On the share stage, students are asked to share ideas or information to a larger scope or present the discussion result in front of the class. While according to Supardi [15] Think-Pair-Share learning consists of three main stages: think 
- means that students think individually about the problem, pair - means that students discuss the answer with partners, and share - means that students in pair share the answer in front of the class and other students give response about it. According to Azlina [6], to fulfill the concept of Think-PairShare, all of the three stages of think, pair, and share is provided with a 'timer', where the supervisor/ teacher is able to set the time for each task, while the students need to conclude their answers within the specified time. The ThinkPair-Share can train the students' communication ability. Each student has the opportunity to speak, discuss to solve problem and participate in conveying the discussion result in front of the class so that they feel more confident and can be more active in class. According to Mutakinati [5], the benefit of using the Think-Pair-Share, includes the positive changes in students' communication ability that occur when they listen to one another and respect others' ideas. By applying the ThinkPair-Share learning, students will work individually then in group. It gives students some time to show their participation by conveying the discussion result, asking or giving opinion [8].

Contextual approach is a method to relate the taught material and the real life and encourage students to make connection between the knowledge they have and the application on their eveyday life [9]. Khotimah [20] argues that Contextual Teaching and Learning (CTL) is one of learning approaches that makes use of everyday life problems or problems around the students as their learning objects. Contextual approach is a way of learning to help teacher bring the real world into the learning and encourage students to relate the material they learn and its application on life [10]. Therefore, students are aware what they learn is useful in everyday life. Johnson [11] argues that contextual learning is a learning aimed to help students learn the material meaningfully by relating the lesson and everyday life. In addition, contextual learning is one of learnings that can make the learning more concrete and meaningful. Contextual teaching and learning approach applies seven components to create an effective teaching and learning process[12]. The components of contextual learning are: grouping, modelling, questioning, learning community, inquiry, constructivism and authentic assessment [13]. Contextual approach emphasizes on the importance of problem solving so that by using it, the students' problem solving ability is increased [14][21].

Think-Pair-Share learning with contextual approach is a learning that uses the steps of Think-Pair-Share learning and the components of contextual approach. Think-Pair-Share learning with contextual approach requires students to be active in learning. This is a student-centered learning in which knowledge and concept are found and built by the students themsleves, not by the teacher. The mathematical problems are solved individually by students, then they are discussed in pairs so that students exchange ideas one another in solving the problems. During the discussion activity, students exchange the information through presentation, question and answer and conveying of opinion.

The aim of this research was to find out the effect of ThinkPair-Share learning with contextual approach on students' problem solving ability.The hypothesis of the research was, there is an effect of think-pair-share learning with contextual approach on students' problem solving, in which problem solving ability of students in experimental group is better than the problem solving ability of students in control group.

\section{METHOD}

This research used test method with the research instrument of problem solving ability. The static group comparison design was used as the research design. The subject of the research was the $8^{\text {th }}$ grade junior high school students, consisted of two groups, namely experimental group and control group. The experimental group $(n=28)$ was the class which was given treatment of Think-Pair-Share learning with contextual approach, while the control group $(n=30)$ was the class which was not given any treatment.

The data analysis technique used to test the hyputhesis in this research was t-statisctic test with significance level $\alpha=$ 0.05 . Before performing the hypothesis test using t-statistical test, the researcher performed normality test and test for homogeneity of variance. Normality test is used to find out whether the two sample groups are normally distributed. If both of the analysed data are normally distributed, then it proceeds with parametric test namely test for homogeneity of variance. However, if both of the analysed data or one of them are not normally distributed, then it proceeds with nonparametric statistical test namely Mann Whitney U test [17]. Homogeneity test is a test which has to be performed to see if the two sample groups under the study have the same level of variance. If the analysed data are normally distributed and homegeneous, the hypothesis test will be conducted using t-statistic test. The data analysis was done manually. This statistical test was performed by taking a decision with the provision if $t_{\text {count }}>t_{\text {table }}$ then $\mathrm{H}_{0}$ is rejected, it means that the students' mathematics problem solving ability in experimental group who is taught using Think-Pair-Share learning with contextual method is better than the students' mathematics problem solving ability in the control group.

\section{RESULT}

Based on the calculation of students' problem solving ability test, the mean score of students in the experimental group was 86.53 from the total score of 100 and the standard deviation of 12.93. While the mean score of the control group was 67.68 from the total score of 100 and the standard deviation of 10.57. Before performing hypothesis test using tstatistic test, the researcher firstly performed normality and homogeneity test. The result of normality test for the experimental group using chi-square statistic test was $x_{\text {rmant }}^{2}=-47.74$ and $x_{\text {tahin }}^{2}=7.81$. Because $x_{\text {fromt }}^{2}<x_{\text {tahla }}^{2}(-47.74<7.81)$, then the data of the experimental group was normally distributed. Furthermore, normality test was also performed for the control group using chi-square statistic test. The result was $x_{\text {rmant }}^{2}=-32.86$ and $x_{\text {tahle }}^{2}=7.81$. Because $x_{\text {minnt }}^{2}<x_{\text {trhla }}^{2}(-32.86<7.81)$ then the data of the control group was normally distributed. It can be concluded 
that in normality test, the data of the experimental group and control group were normally distributed.

Then the researcher performed test for homogeneity of variance using F-statistic test. The result of homogeneity test of the experimental group and control group was $F_{\text {count }}=1.22$ and $F_{\text {table }}=1.87$ so that $F_{\text {count }}<F_{\text {table }}(1.22<1.87)$. Based on the result of test for homogeneity of variance, it can be concluded that the data of the experimental group and control group were homogenous.

Hypothesis test used t-statistic test, with criteria $\mathrm{H}_{0}$ is rejected if $t_{\text {count }}>t_{\text {table }}$. The result of t-statistic test analysis can be seen in Table 1 and Table 2 .

TABLE I. DATA RECAPITULATION OF EXPERIMENTAL GROUP AND CONTROL GROUP

\begin{tabular}{|l|c|c|c|}
\multicolumn{4}{|c}{ AND CONTROL GROUP } \\
\hline Group & $\mathrm{N}$ & Mean $(\overline{\boldsymbol{X}})$ & $\begin{array}{c}\text { Standard } \\
\text { Deviation } \\
(\mathrm{SD})\end{array}$ \\
\hline Conperimental & 28 & 86.53 & 12.93 \\
\hline
\end{tabular}

TABLE II. .RECAPITULATION OF T-STATISTIC TEST

\begin{tabular}{|l|c|c|c|c|}
\hline Group & $\begin{array}{c}\text { Significance } \\
\text { Level }\end{array}$ & $t_{\text {count }}$ & $t_{\text {table }}$ & $H_{0}$ Rejected/Accepted \\
\hline $\begin{array}{l}\text { Experimen } \\
\text { tal }\end{array}$ & 0.05 & 21.03 & 1.64 & $H_{0}$ is rejected \\
\hline Control & & & & \\
\hline
\end{tabular}

The result of hypothesis test which was performed using tstatistic test with significance level 0.05 and $\mathrm{df}=56$ was $t_{\text {count }}=21.03$ and $t_{\text {table }}=1.64$ so that $t_{\text {count }}>t_{\text {table }}(21.03>1.64)$. It can be concluded that $\mathrm{H}_{0}$ is rejected. This indicated that there was a difference in the score of students' problem solving in experimental group (using treatment of Think-Pair-Share learning with contextual approach) and control group (using no treatment). This means that problem solving ability of students in experimental group was better than the problem solving ability of students in control group. It can be concluded that Think-Pair-Share learning with contextual approach has an effect on students' problem-solving ability.

\section{DISCUSSION}

The mean score of problem solving ability of students in experimental group and control group were 86.53 and 67.68 respectively. This result indicated that the mean score of the students' problem solving ability in experimental group is higher than those in control group. It shows that Think-PairShare learning with contextual approach in mathematics learning in experimental group was better than those in control group. It is because this learning begins with the stage of individual thinking or solving contextual problem individually, then discussing the result of individual thinking to the pair and solving the given problem together then finally presenting the discussion result in front of the class [18]. However, in this research, the items of problem solving test did not cover all the mathematics material taught in junior high school. Therefore, the students' problem solving ability cannot generalize the students' mathematical ability in all materials as a whole.

\section{CONCLUSION}

Based on the research result, the mean score of the problem soving ability of students in experimental group was 86.53 and the mean score in control group was 67.68. The result of hypothesis test using t-statistic test with siginficance level 0.05 and $\mathrm{df}=56$ was $\boldsymbol{t}_{\text {count }}=\mathbf{2 1 . 0 3}$ and $\boldsymbol{t}_{\text {table }}=1.64$ so that $t_{\text {count }}>\boldsymbol{t}_{\text {table }}\left(\mathbf{2 1 . 0 3}>\mathbf{1 . 6 4 )}\right.$ and $\mathrm{H}_{0}$ was rejected. It means that the students' problem solving ability in experimental group was better than those in control group. It can be conculded that there is a significant effect of ThinkPair-Share learning with contextual approach on junior high school students' mathematics problem solving ability. Therefore, Think-Pair-Share learning with contextual approach can be used as a reference to conduct learning in mathematics class as well as to train students' problem-solving ability. Further research that needs to be conducted is to explore the increase of students' problem-solving ability on the different academic level.

\section{REFERENCES}

[1] M. Ing, "Student Participation in Elementary Mathematics Classroom: The Missing Link Between Teacher Practices and Student Achievement?", Educational Studies in Mathematics, vol. 90, no. 3, pp. 341-356, 2015.

[2] S. S. Nyunt and E. E. Tint, "Collaborative Learning With Think Pair Share Technique", Computer Applications: An International Journal, vol. 2, No. 1, pp. 1-11, 2015.

[3] R. I. Arends, Learning to Teach 10th Edition, New York: McGraw-Hill, 2016.

[4] Umamet, The Effect of Think-Pair-Share Cooperative Learning Model Assisted With ICT on Mathematical Problem Solving Ability among Junior High School Students, New Zealand: Asia-Pacific Society for Computers in Education, 2017, pp. 94-98

[5] L. Mutakinati, "Cooperatif Learning Think Pair Share (TPS) for Improving Students' Problem Solving Skill in Buffer Solution Concept", Journal of Social Science Education, vol. 29, No. 9, pp. 11-14, 2015.

[6] N. A. N. Azlina, "CETLs : Supporting Collaborative Activities Among Students and Teachers Through the Use of Think-Pair-Share Techniques", International Journal of Computer Science, vol. 7, No. 5, pp. 18-29, 2010.

[7] A. Lie, Cooperatif Learning: Mempraktikan Cooperatif Learning di Ruang-Ruang Kelas, Jakarta: Grasindo, 2005.

[8] M. Huda, Model-Model Pengajaran dan Pembelajaran, Malang: Pustaka Pelajar, 2010.

[9] Nurhadi and A. G. Senduk, Pembelajaran Kontekstual, Malang: PT. Jepe Press Media Utama, 2009.

[10] E. Siregar and H. Nara, Teori Belajar dan Pembelajaran, Bogor: Ghalia Indonesia, 2011.

[11] D. W. Johnson and R. T. Johnson, Meaningful Assessment A Manageable and Cooperative Process, Boston: Allyn and Bacon, 2002.

[12] D. Selvianiresa and S. Prabawanto, "Contextual Teaching and Learning Approach of Mathematics in Primary Schools", Journal of Physics: Conference Series, pp. 1-7, 2017.

[13] K. E. Lestari and M. R. Yudhanegara, Penelitian Pendidikan Matematika, Bandung: PT Refika Aditama, 2015. 
[14] J. Nome, "The Development of Contextual Learning Tools to Improve Problem Solving Ability on Simultaneous Linear Equations For Grade VIII Students", Mathematics, Science, and Computer Science Education, 2017.

[15] Supardi and I. Zukarnain, "The Effect Cooperative Learning Model Resolution of Mathematics Problem Solving and Students' Mathematics Communication", Journal of Educational Research and Review, vol. 3, no. 4, pp. 44-53, 2015.

[16] A. A. Raba, "The Influence of Think-Pair-Share (TPS) on Improving Students' Oral Communication Skills in EFL Classrooms", Creative Education, vol. 8, pp. 12-23, 2017.

[17] N. Nachar, "The Mann-Whitney U: A Test for Assessing Whether Two Independent Samples Come from the Same Distribution", Tutorials in Quantitative Methods for Psychology, vol. 4, no.1, pp. 13-20, 2008.
[18] D. Sugiarto and P. Sumarsono, International Journal of English and Education, vol.3, pp. 206-215, 2014.

[19] A. Sampsel, "Finding the Effects of Think-Pair-Share on Student Confidence and Participation", Honors Projects, vol. 28, 2013.

[20] R. P. Khotimah and Masduki, "Improving Teaching Quality and Problem Solving Ability Through Contextual Teaching and Learning in Differential Equations: A Lesson Study Approach", Journalof Researchand Advancesin MathematicsEducation, vol. 1, no. 1, pp.1-13, 2014.

[21] I. Widiati, "Developing Mathematical Problem Solving Skills of Students Junior High School Through Contextual Learning”, pp. 273$278,2014$. 